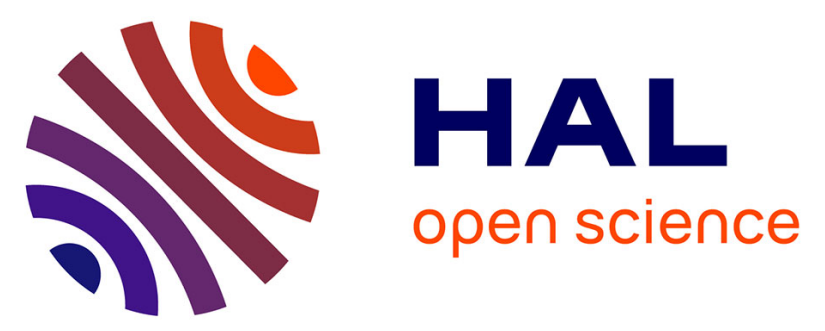

\title{
Dipolar self-potential anomaly associated with carbon dioxide and radon flux at Syabru-Bensi hot springs in central Nepal
}

S. Byrdina, André Revil, S.R. Pant, B. P. Koirala, P. L. Shrestha, D.R.

Tiwari, U. P. Gautam, K. Shrestha, S.N. Sapkota, S. Contraires, et al.

\section{To cite this version:}

S. Byrdina, André Revil, S.R. Pant, B. P. Koirala, P. L. Shrestha, et al.. Dipolar self-potential anomaly associated with carbon dioxide and radon flux at Syabru-Bensi hot springs in central Nepal. Journal of Geophysical Research: Solid Earth, 2009, 114, pp.B10101. 10.1029/2008JB006154 . insu-00498635

\section{HAL Id: insu-00498635}

\section{https://hal-insu.archives-ouvertes.fr/insu-00498635}

Submitted on 6 Aug 2020

HAL is a multi-disciplinary open access archive for the deposit and dissemination of scientific research documents, whether they are published or not. The documents may come from teaching and research institutions in France or abroad, or from public or private research centers.
L'archive ouverte pluridisciplinaire HAL, est destinée au dépôt et à la diffusion de documents scientifiques de niveau recherche, publiés ou non, émanant des établissements d'enseignement et de recherche français ou étrangers, des laboratoires publics ou privés. 


\title{
Dipolar self-potential anomaly associated with carbon dioxide and radon flux at Syabru-Bensi hot springs in central Nepal
}

\author{
S. Byrdina, ${ }^{1}$ A. Revil, ${ }^{2,3}$ S. R. Pant, ${ }^{4}$ B. P. Koirala, ${ }^{5}$ P. L. Shrestha, ${ }^{5}$ D. R. Tiwari, ${ }^{5}$ \\ U. P. Gautam, ${ }^{5}$ K. Shrestha, ${ }^{4}$ S. N. Sapkota, ${ }^{5}$ S. Contraires, ${ }^{6}$ and F. Perrier ${ }^{7}$
}

Received 14 October 2008; revised 7 April 2009; accepted 25 June 2009; published 3 October 2009.

[1] The Syabru-Bensi hot springs are located at the Main Central Thrust (MCT) zone in central Nepal. High carbon dioxide and radon exhalation fluxes (reaching $19 \mathrm{~kg} \mathrm{~m}^{-2} \mathrm{~d}^{-1}$ and $5 \mathrm{~Bq} \mathrm{~m}^{-2} \mathrm{~s}^{-1}$, respectively) are associated with these hot springs, making this site a promising case to study the relationship between self-potential and fluids (gas and water) exhalation along a fault zone. A high-resolution self-potential map, covering an area of $100 \mathrm{~m}$ by $150 \mathrm{~m}$ that surrounds the main gas and water discharge spots, exhibits a dipolar self-potential anomaly with a negative peak reaching $-180 \mathrm{mV}$ at the main gas discharge spot. The positive lobe of the anomaly reaching $120 \mathrm{mV}$ is located along the terraces above the main gas and water discharge spots. Several electrical resistivity tomograms were performed in this area. The resistivity tomogram crossing the degassing area shows a dipping resistive channel interpreted as a fracture zone channeling the gas and the hot water. We propose a numerical finite difference model to simulate the flow pattern in this area with the constraints imposed by the electrical resistivity tomograms, the self-potential data, the position of the gas vents, and hot water discharge area. This study provides insights on the generation of electrical currents associated with geothermal circulation in a geodynamically active area, a necessary prerequisite to study, using self-potentials, a possible modulation of the geothermal circulation by tectonic activity.

Citation: Byrdina, S., et al. (2009), Dipolar self-potential anomaly associated with carbon dioxide and radon flux at Syabru-Bensi hot springs in central Nepal, J. Geophys. Res., 114, B10101, doi:10.1029/2008JB006154.

\section{Introduction}

[2] Self-potential signals are the electrical field signature of the occurrence of natural polarization mechanisms inside geological systems [e.g., Nourbehecht, 1963]. Source contributions include the drag of the excess of electrical charge occurring in the vicinity of the pore water interface by the flow of the pore water, the so-called streaming potential contribution, [e.g., Nourbehecht, 1963; Sill, 1983; Boléve et

\footnotetext{
${ }^{1}$ Laboratoire Magmas et Volcans Observatoire de Physique du Globe de Clermont-Ferrand, Université Blaise Pascal, IRD M163, UMR 6524, Clermont-Ferrand, France.

${ }^{2}$ Colorado School of Mines, Green Center, Department of Geophysics, Golden, Colorado, USA.

${ }^{3}$ Laboratoire de Géophysique Interne et Tectonophysique, UMR 5559, Université de Savoie, Equipe de Volcanologie, CNRS, Le Bourget du Lac, France.

${ }^{4}$ Central Department of Geology, Tribhuvan University, Kirtipur, Nepal.

${ }^{5}$ National Seismological Centre, Department of Mines and Geology, Lainchaur, Kathmandu, Nepal.

${ }^{6}$ Equipe de Géomatériaux et Environnement, IPGP, UMR 7154, Paris, France.

${ }^{7}$ Université Paris Diderot and Equipe de Géomagnétisme, IPGP, UMR 7154, Paris, France.

Copyright 2009 by the American Geophysical Union. 0148-0227/09/2008JB006154\$09.00
}

al., 2007b], thermoelectric and electrodiffusional phenomena [e.g., Sill, 1983; Revil et al., 1999; Darnet et al., 2004; Maineult et al., 2006], and electroredox phenomena [Naudet et al., 2003; Minsley et al., 2007; Castermant et al., 2008]. Maps of self-potential signals are easy to perform because they only require two nonpolarizing electrodes and a sensitive voltmeter (sensitivity $\sim 0.1 \mathrm{mV}$ ) with high input impedance $(\geq 100 \mathrm{M} \Omega)$. A self-potential anomaly is defined as a spatial variation of the electrical potential distribution, at the surface of the Earth or in boreholes, with respect to a reference electrode, located far enough from the disturbed zone.

[3] With the exception of the presence of ore and graphite mineralization, the self-potential anomalies observed in geothermal field and active volcanoes are mainly associated with the flow of the groundwater [e.g., Corwin and Hoover, 1979; Goldstein et al., 1989; Zlotnicki and Nishida, 2003; Finizola et al., 2003; Jardani et al., 2008]. A vigorous flow of groundwater can generate self-potential anomalies of the order of several hundreds of millivolts [e.g., Sasai et al., 1997; Ishido et al., 1997; Lénat et al., 1998; Lewicki et al., 2003; Aizawa et al., 2005; Finizola et al., 2006] and sometimes of several volts [Finizola et al., 2004]. Therefore, a number of researches have been conducted to model the self-potential anomalies in terms of groundwater flow 
and thermohydromechanical disturbances [Corwin and Hoover, 1979; Revil and Pezard, 1998; Revil et al., 2004, 2005; Wilkinson et al., 2005; Jardani et al., 2006; Crespy et al., 2008; Revil et al., 2008].

[4] Streaming self-potential signals are generated by the divergence of the streaming current density associated with the convective drag of the excess of electrical charges contained in the pore water [Sill, 1983]. This implies that (1) understanding the polarity and strength of self-potential signals requires to solve an electrostatic Poisson equation using the resistivity distribution of the system [Sill, 1983; Revil and Pezard, 1998; Jardani et al., 2008] and (2) some groundwater flow patterns are not associated with any selfpotential anomalies outside the source volume of groundwater flow (they are called annihilators by Jardani et al. [2008]).

[5] In pursuing this study, we have two goals. The former lies in the understanding of large-scale dipolar self-potential anomalies related to geothermal activity. Such anomalies have been observed in various areas of the world [Corwin and Fitterman, 1982; Goldstein et al., 1989; Schima et al., 1995; Apostolopoulos et al., 1997; Revil and Pezard, 1998; Jardani et al., 2008]. The quantitative interpretation of these self-potential anomalies is not straightforward because of the influence of different parameters like temperature, the fluid pressure, the permeability, the $\mathrm{pH}$ and salinity of the pore fluid [e.g., Sill, 1983; Yasukawa et al., 1993; Ishido and Pritchett, 1999; Aizawa et al., 2005; Uyeshima, 2007; Revil et al., 2008; Jardani et al., 2008]. Therefore, the selfpotential can be used to constrain the geometry of groundwater flow only if additional and independent geological and geophysical information are available or can be inferred with a good accuracy [Finizola et al., 2006; Revil et al., 2008]. Acquisition of these complementary information at large scales is challenging and rarely performed. This problem justifies our interest for small-scale geothermal systems where modeling can be reasonably attempted and additional information easily gathered. One of the main applications of the self-potential method in these areas would be the nonintrusive estimate of the permeability of the faults acting as permeable fluid flow pathways.

[6] The second goal is related to fault activity. We believe indeed that such a detailed investigation is highly desirable in tectonically active areas because the time variations of the flux of gases and electrical signals could be related to the modulation of the tectonic stresses, at large scales, in the preparation phase of strong earthquakes or during the earthquakes themselves [Park et al., 2007] and/or by the existence of shock waves moving along fault planes [Revil and Cathles, 2002a, 2002b].

[7] In this paper, we present the results of a multiparameter investigation performed at a small-scale hydrothermal vent located around the Syabru-Bensi hot springs in central Nepal. Self-potential signals, discharge rates, and chemical composition of these hot springs, as well as ${ }^{222} \mathrm{Rn}$ and $\mathrm{CO}_{2}$ gas exhalation fluxes have been independently measured. This hydrothermal vent presents a particular interest because it is characterized by high exhalation fluxes observed over a confined area of few hundred square meters. This area is easily accessible for a detailed self-potential gas flux mapping as well as for high-resolution resistivity tomographies.

\section{Syabru-Bensi Hot Springs}

[8] The Syabru-Bensi hot springs, located $52 \mathrm{~km}$ north of Kathmandu, are part of a series of hot springs (Figure 1a) found along the Main Central Thrust (MCT) zone [Evans et al., 2004]. The MCT separates Lesser Himalayan Precambrian to Paleozoic metasediments to the south, from Higher Himalayan Crystallines to the north [Upreti, 1999]. This thrust zone, usually considered inactive, is supposed to be branching at depth to the Main Himalayan Thrust (MHT). The MHT is the main structure accommodating the collision of India and Tibet [Bollinger et al., 2004]. Microseismicity and moderate earthquakes are mainly concentrated at mid crustal depth on a ramp of the MHT [Pandey et al., 1999]. Large Himalayan earthquakes, by contrast, activate a large section of the MHT from the higher Himalayas to its surface trace, referred to as the Main Frontal Thrust (MFT) in southern Nepal [Lavé et al., 2005]. The Syabru-Bensi hot springs are therefore located less than $10 \mathrm{~km}$ away from the nucleation zone of potentially large Himalayan earthquakes. This makes this area particularly interesting to monitor seismic activity using unconventional methods.

[9] The hot springs in Syabru-Bensi are located at the lower flank of an alluvial terrace incised by the Trisuli River (Figure 1b). Several springs on the left bank are covered by the river most of the time. On the right bank, most springs are located a few meters above the Trisuli. The site has been equipped with cemented basins and is traditionally used for ritual and domestic purposes by local Tamang, Tibetan, and Sherpa people (Figure 2). In this paper, we are mostly concerned with the area around these main springs. Their composition is given in Table 1 . They are characterized by temperatures varying from 35 to $60{ }^{\circ} \mathrm{C}$ and flow rates varying between 0.06 and $0.3 \mathrm{~L} \mathrm{~s}^{-1}$ depending on the discharge point. The electrical conductivities of spring waters vary from 1200 to $1900 \mu \mathrm{S} \mathrm{cm}{ }^{-1}$, corresponding to an electrical resistivity from 5 to $8 \Omega \mathrm{m}$ [Perrier et al., 2009]. The hottest and most saline water is collected by a plastic pipe (SBP0) from a spring located a few meters downstream of the basins (Figure 2).

[10] Gas discharges are observed around cavities of few tens of centimeters deep in the debris slope above the springs (Figure 2). The gas is mainly carbon dioxide. Isotopic ${ }^{13} \mathrm{C}$ anomalies of hot springs in Nepal (including Syabru-Bensi hot springs) suggest a mechanism of metamorphic decarbonation followed by intense degassing [Evans et al., 2008; Becker et al., 2008]. The Syabru-Bensi hot springs could provide a prototype of carbon dioxide and fluid flow release to the atmosphere associated with active tectonics and orogenic processes.

[11] The diffusive gas flux on the ground was mapped by the accumulation chamber method. At main locations labeled as GD1, GD1b, and GD2 in Figure 2, values as high as $19 \mathrm{~kg} \mathrm{~m}^{-2} \mathrm{~d}^{-1}$ have been observed [Perrier et al., 2009]. These flux values exceed by thousand times a background level in the area, and are comparable to the $\mathrm{CO}_{2}$ flux values recorded on active volcanoes [e.g., Lewicki et al., 2003; Finizola et al., 2006; Revil et al., 2008]. The gas discharges GD1 and GD1b are located in the terrace above the water 

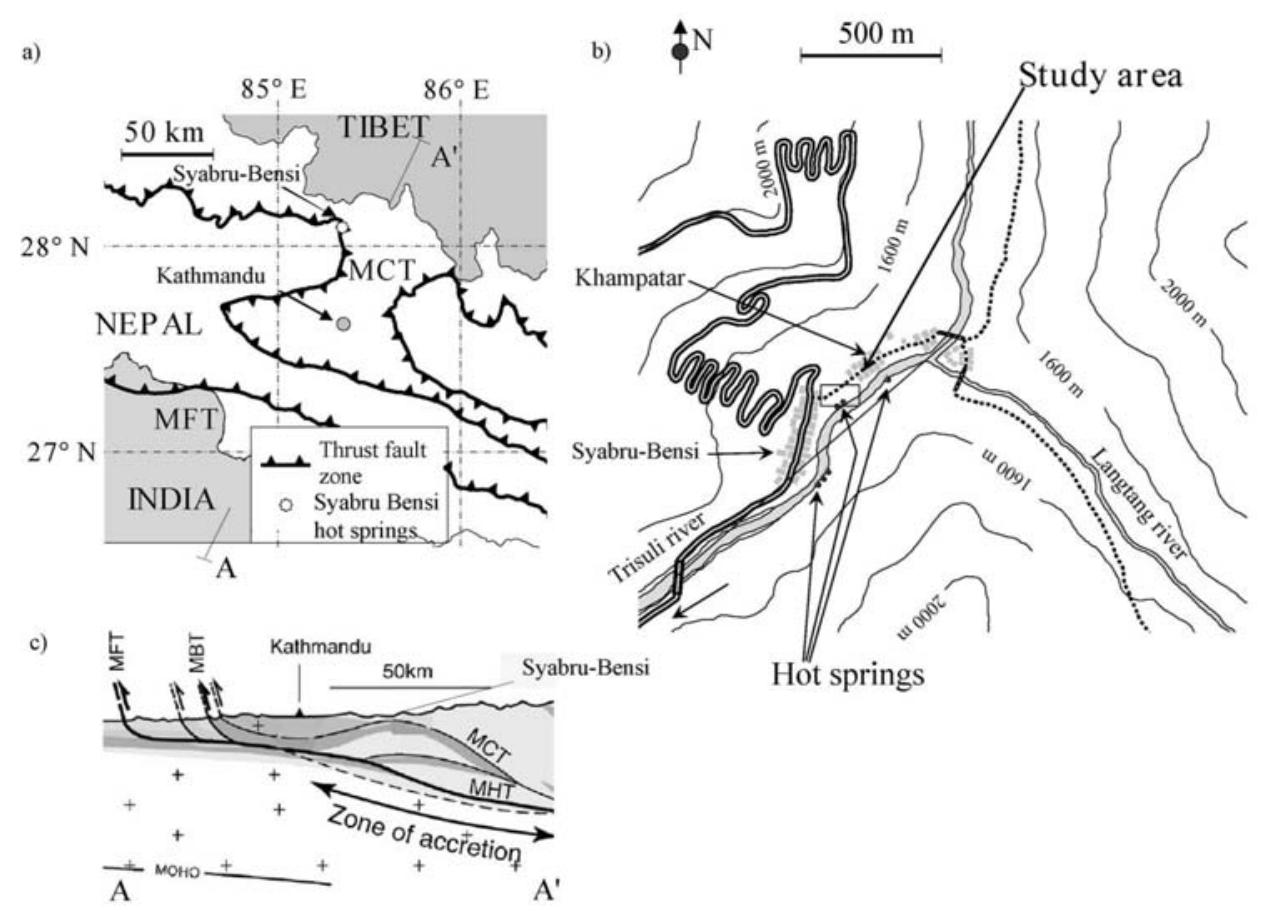

Figure 1. Localization of the survey area. (a) Simplified map of central Nepal with contours of Main Central Thrust (MCT), Main Fault Thrust (MFT), and location of the Syabru-Bensi hot springs. (b) Map of the site and localization of the study area (rectangle on the right side of the Trisuli River). Hot springs are observed on the both sides of the Trisuli River. Grey rectangles denote the position of the houses, and the dotted lines indicate the trails. (c) Simplified section across AA $^{\prime}$ profile shown in Figure 1a (after Bollinger et al. [2006] with permission from Elsevier).

spring (Figure 2) and have been studied in more detail [Perrier et al., 2009]. Gas discharge GD2, located in the steep slope just above the water basins, is more difficult to access and has therefore been studied less intensely. A flux with a value larger than $1 \mathrm{~kg} \mathrm{~m}^{-2} \mathrm{~d}^{-1}$ is observed up to 5 to $10 \mathrm{~m}$ around the main gas discharges. This carbon dioxide flux is associated with an anomalous high ${ }^{222} \mathrm{Rn}$ flux, reaching $5 \mathrm{~Bq} \mathrm{~m}^{-2} \mathrm{~s}^{-1}$, a value, comparable with values commonly measured on uranium waste [Bollhöfer et al., 2006]. High radon flux associated with anomalous carbon dioxide flux at Syabru-Bensi gas discharge points suggest their connection to the pressurized zone at depth [Perrier et al., 2009].

\section{Field Investigations}

[12] Self-potential mapping was performed from 28 December 2006 to 6 January 2007, namely, in the middle of the dry season, which, in this part of the Himalayas, lasts from November to March. During the mapping, the weather was sunny with no rainfall over more than a month. In this season, there is no agricultural activity in the mapped area. Vegetation is dry except for few isolated trees.

[13] Self-potential measurements were performed using nonpolarizable second generation Petiau $\mathrm{Pb} / \mathrm{PbCl}_{2}-\mathrm{NaCl}$ electrodes [Petiau, 2000] and a high impedance Metrix Mx20 voltmeter with sensibility about $0.1 \mathrm{mV}$. These electrodes are characterized by an internal resistance of about $200 \Omega$, a stability better than $0.1 \mathrm{mV}$ over a period of 1 year and a temperature sensitivity of about $200 \mu \mathrm{V}^{\circ} \mathrm{C}^{-1}$ [Petiau, 2000]. Contact between the soil and the electrodes was checked using an $\mathrm{AC}$ ohm meter at $2 \mathrm{kHz}$ and was found to be satisfactory with a maximal value of $35 \mathrm{k} \Omega$. The soil was wet enough to ensure a good electrical contact. The reference electrode was placed in a not disturbed location (background values of both radon and carbon dioxide fluxes), but, because of practical reasons, relatively close to the gas discharges. Stability of the pair of electrodes used for mapping was checked by measuring their potential difference in the storage box. The difference of electrical potential was always smaller than $0.2 \mathrm{mV}$. Mapping was carried out on an area of approximately $100 \mathrm{~m} \times 150 \mathrm{~m}$ around the hot sources and gas discharge spots. It included over 1000 data points (Figure 4). Data interpolation shown in Figure 5 was performed using 2-D biharmonic spline interpolation technique [Sandwell, 1987]. This map will be interpreted below in section 4 .

[14] Electrical resistivity tomography (ERT) profiles were carried out with a Terrameter SAS $300 \mathrm{C}$ and Terrameter SAS2000 Booster from ABEM ${ }^{\mathrm{TM}}$. Several profiles were performed in the Syabru-Bensi area. In this paper, we use the results of two short pole-dipole profiles ERTa and ERTb (Figure 2) with a total length of $48 \mathrm{~m}$ each and $1.5 \mathrm{~m}$ minimal electrode spacing. We label these profiles ERTa and ERTb, respectively. Their positions are shown in Figures 2 and 4 . The topography along the profile was measured by a leveling technique to an accuracy of $\sim 10 \mathrm{~cm}$. Pole-dipole configuration has relatively good penetration 


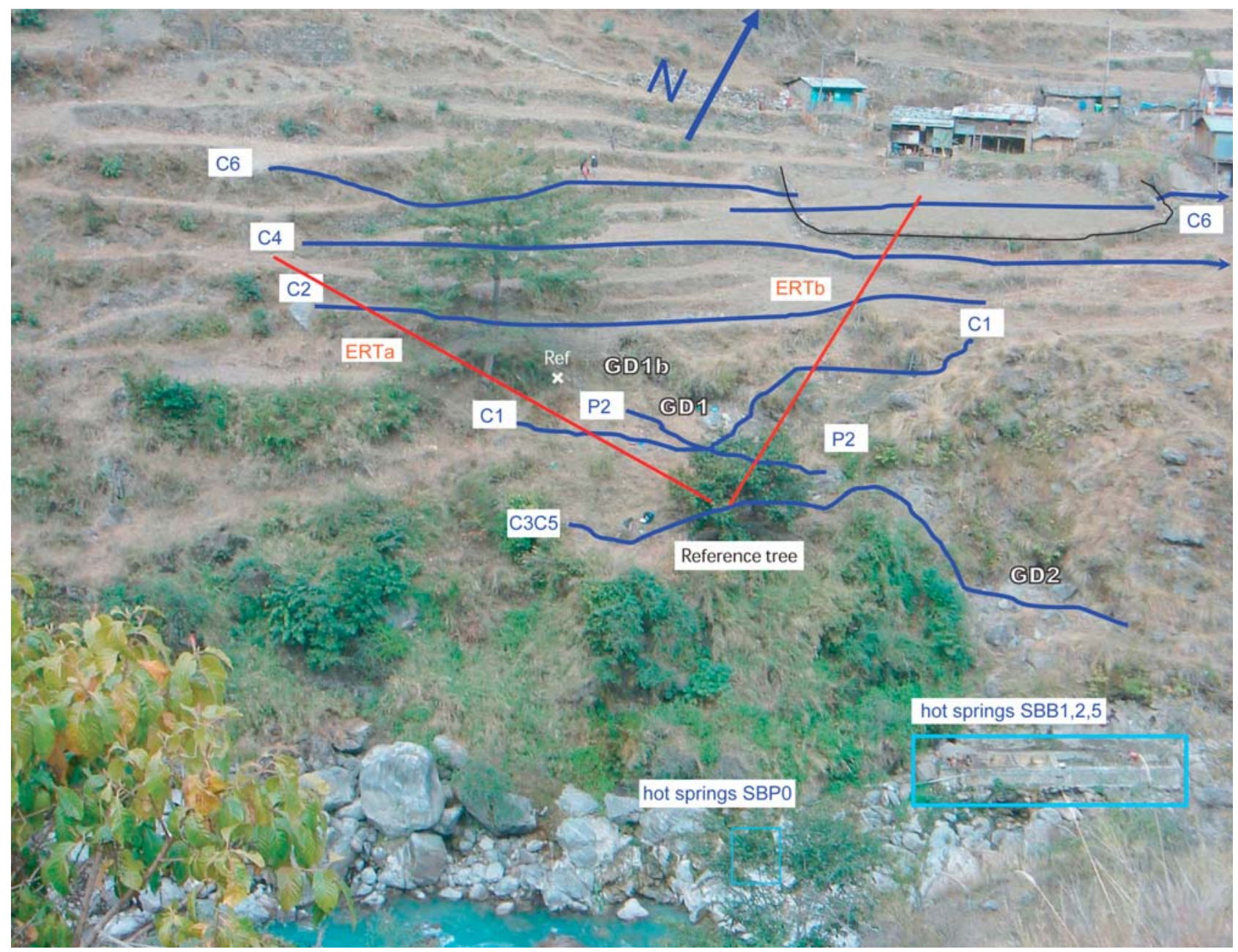

Figure 2. Study area around the hot springs (noted SBB 1-5 as in the work by Perrier et al. [2009]) and main gas discharge points GD1, GD1b, and GD2 with sulphate and sulfide deposits. Red solid lines indicate electrical resistivity tomography profiles (ERTa and ERTb), blue lines show $\mathrm{CO}_{2}$ profiles, and the white cross indicates the self-potential reference point (Ref).

and is well adapted for areas with lateral heterogeneity and in the area where contrast in the electrical resistivities is not very high [Ward, 1989].

[15] Two-dimensional data inversion was performed using RES2DINV (Geotomo Software ${ }^{\mathrm{TM}}$ ) [Loke and Barker, 1996], which uses the smoothness-constrained method to perform the inverse problem [Constable et al., 1987]. The normalized root-mean-square (RMS) of a resistivity section is defined by

$$
D_{\text {rms }}=\left[\frac{1}{N} \sum_{i=1}^{N}\left(\frac{\rho_{a(o b s)}-\rho_{a(c a l c)}}{\rho_{a(o b s)}}\right)^{2}\right]^{1 / 2} 100 \%
$$

where $N$ is the number of measurements used to build the apparent resistivity pseudosection [e.g., Olayinka and Yaramanci, 2000].

[16] The algorithm tries to reduce this quantity in an attempt to find a better model after each iteration. In our case, we also included the topography in the inversion of the apparent resistivity data. The normalized RMS errors of our two profiles were below $5 \%$ at the fifth iteration $(3.5 \%$ for ERTa and $4.4 \%$ for ERTb profile). This usually means that the apparent resistivity data are properly reproduced by the inverted resistivity model. Because the electrical resistivity tomograms exhibits patterns that are geologically and hydrogeolocally meaningful (see sections 4 and 5), we believe that we can use ERT data for the modeling of the

Table 1. Composition of the Pore Water at Syabru-Bensi Springs ${ }^{\mathrm{a}}$

\begin{tabular}{lc}
\hline Element & Concentration $\left(\mu \mathrm{mol} \mathrm{L} \mathrm{L}^{-1}\right)$ \\
\hline $\mathrm{Na}^{+}$ & 8230 \\
$\mathrm{~K}+$ & 2206 \\
$\mathrm{Ca}_{2}^{+}$ & 3289 \\
$\mathrm{Mg}^{2+}$ & 2411 \\
$\mathrm{Li}^{2+}$ & 559 \\
$\mathrm{Fe}^{2+}$ & 30 \\
$\mathrm{HCO}_{3}^{-}$ & 19,320 \\
$\mathrm{~F}^{-}$ & 80 \\
$\mathrm{Cl}^{-}$ & 949 \\
$\mathrm{SO}_{4}^{2-}$ & 1052 \\
\hline
\end{tabular}

${ }^{\mathrm{a}}$ From Perrier et al. [2009]. 


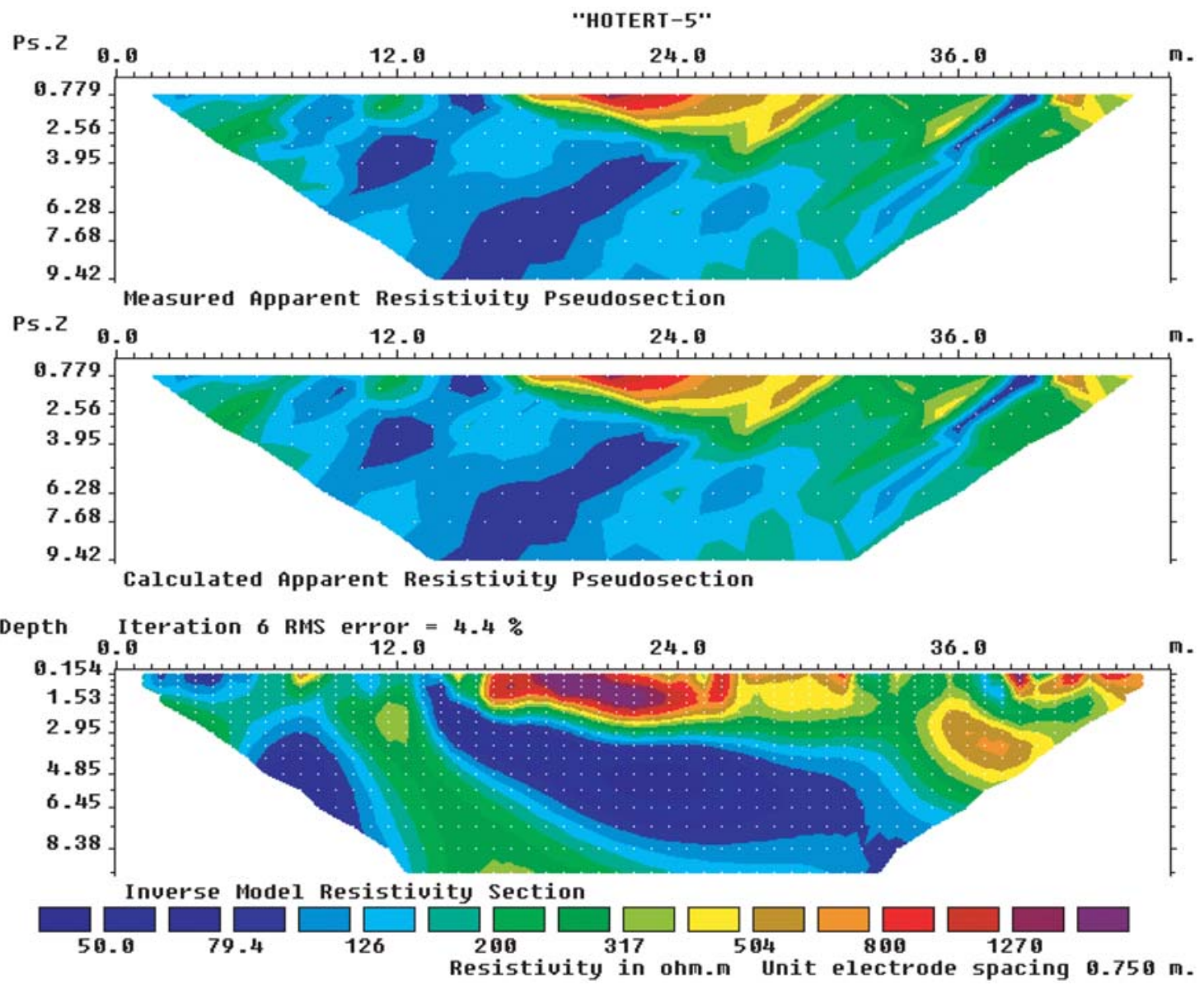

Figure 3. Results of the electric resistivity tomography for profile ERTb. (top) Measured apparent resistivity pseudosection, (middle) calculated apparent resistivity pseudosection, and (bottom) inverse model resistivity.

self-potential data. The quality of the ERT field data can be inspected on Figure 3 presenting a pseudosection and inversion results for ERTb profile. Noteworthy is the low level of near surface variations of apparent resistivity and a similarity over the whole section range between measured and calculated pseudosections.

\section{Results}

[17] The self-potential map is shown in Figure 4. This map includes a large fraction of the alluvial terrace on the right bank of the Trisuli River. For reference, the position of hot springs, several large trees, and the cemented basins shown in Figure 2, are also marked in Figure 4. No selfpotential anomaly was observed in the immediate vicinity of the hot water springs themselves nor next to the Trisuli River. All the self-potential anomalies are localized just above the hot springs and gas discharge spots. The selfpotential map exhibits an extended positive anomaly on the terrace above the Trisuli River bank superimposed with a butterfly shape anomaly around the hot springs. Sometimes, self-potential data display an anticorrelation with elevation, a pattern created by percolation of meteoric waters, called usually the topographic effect. The data shown in Figure 4, however, do not display any systematic anticorrelation with the elevation. The absence of a significant topographic effect is also seen in Figures $7 \mathrm{a}$ and $7 \mathrm{~b}$.

[18] Figure 5a shows a magnification of the self-potential map in the area of interest, around the two main gas discharge spots GD1 and GD2. With respect to this reference station, the self-potential map exhibits a dipolar selfpotential anomaly. The maximum amplitude of the positive lobe of this anomaly is $120 \mathrm{mV}$, its extent is about $90 \mathrm{~m}$ and a width is about $20 \mathrm{~m}$. The negative peak reaches an amplitude of $-180 \mathrm{mV}$. It is divided into two main lobes concentrated around the major gas discharge areas: gas discharges GD1, GD1b, and, separated by about $10 \mathrm{~m}$, gas discharge GD2. The minimum value is $-80 \mathrm{mV}$ in gas discharge GD1 and $-180 \mathrm{mV}$ in gas discharge GD2. The two lobes of the negative anomaly seem to have symmetrical mirror images in the positive anomaly (Figure 5a).

[19] In Figure 5a, the self-potential map is overlain with the spatial structure of the $\mathrm{CO}_{2}$ flux shown as contour lines, and with the fewer locations of radon flux measurements shown by triangles. The uncertainty of the $\mathrm{CO}_{2}$ flux measurements are smaller than $15 \%$ for most flux values but can reach 30 to $50 \%$ for extremely high fluxes exceeding $10 \mathrm{~kg} \mathrm{~m}^{-2} \mathrm{~d}^{-1}$. The uncertainty of the radon flux measurements varies from 20 to $30 \%$ for fluxes of the order of $10^{-2} \mathrm{~Bq} \mathrm{~m}^{-2} \mathrm{~s}^{-1}$ to less than $5 \%$ for fluxes of the order of $1 \mathrm{~Bq} \mathrm{~m}^{-2} \mathrm{~s}^{-1}$ [Perrier et al., 2009]. The negative peak of 


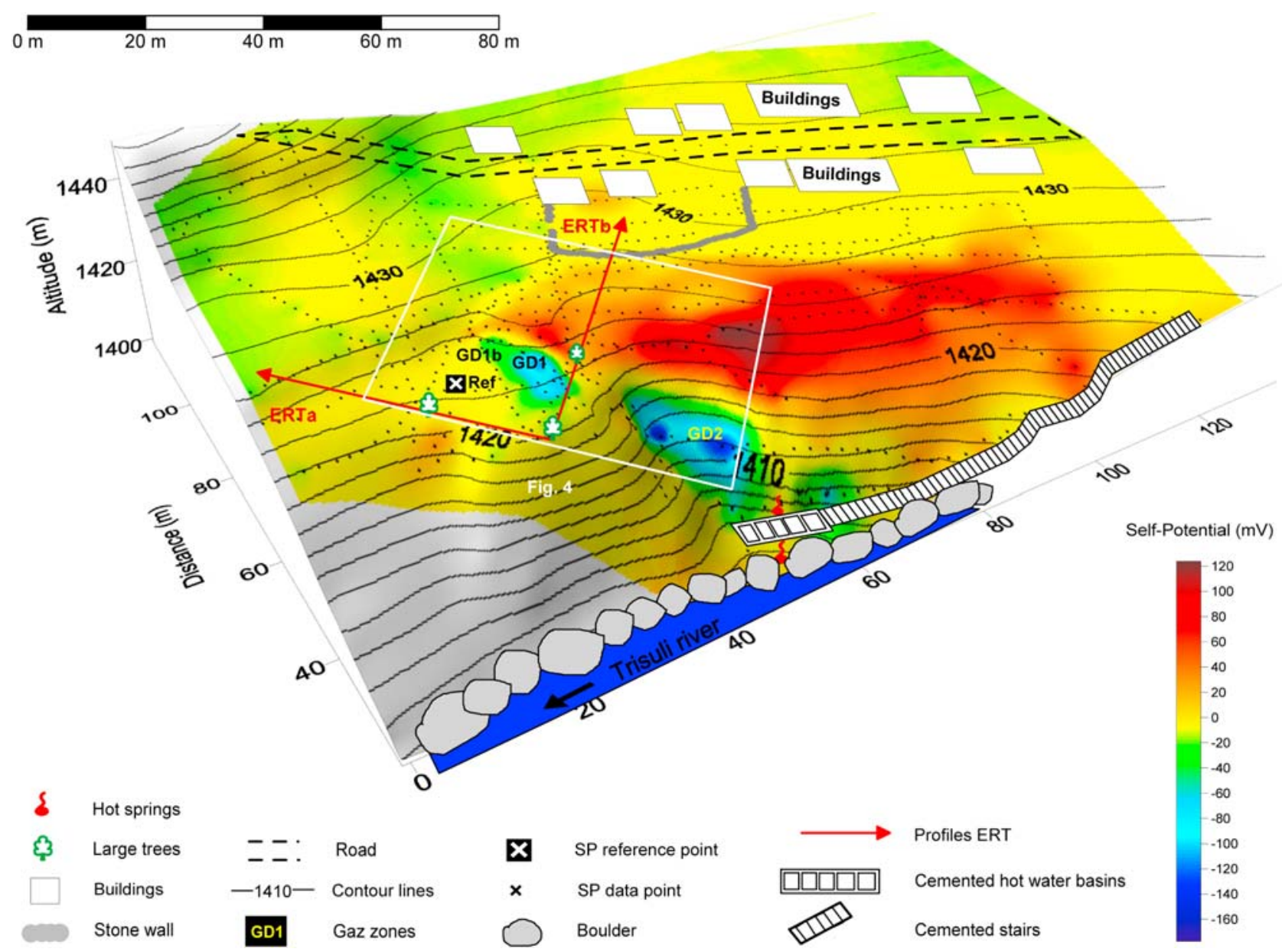

Figure 4. Self-potential map of the area around the hot springs, position of the electrical resistivity tomograms (ERTa and ERTb), and position of the main gas discharge areas (GD1, GD1b, and GD2). The cliffs, trees, terraces, and hot springs basins are shown for reference to Figure 2.

the self-potential anomaly coincides spectacularly with the maximum of $\mathrm{CO}_{2}$ flux and with values of radon flux larger than $2 \mathrm{~Bq} \mathrm{~m}^{-2} \mathrm{~s}^{-1}$. This high gas flux is concentrated next to the foot of the hanging wall of a small ridge of about $2-$ $3 \mathrm{~m}$ height. Significant $\mathrm{CO}_{2}$ flux is also measured over the top of the hanging wall itself, associated with the positive self-potential anomaly. This behavior is best seen on the gas discharge GD1, for which most self-potential and gas flow measurements are available.

[20] The relationship between gas flow and self-potential is rather subtle, as illustrated in Figure 5 showing selfpotential versus radon flux (Figure $5 \mathrm{~b}$ ) and self-potential versus $\mathrm{CO}_{2}$ flux (Figure $5 \mathrm{c}$ ). Whereas self-potential data display large dispersion in Figure $5 \mathrm{~b}$, radon fluxes larger than $1 \mathrm{~Bq} \mathrm{~m}^{-2} \mathrm{~s}^{-1}$ are associated with negative selfpotential values, smaller than $-50 \mathrm{mV}$. A rough general trend for self-potential versus radon flux is shown by a black line representing a linear least squares fit. The relationship between self-potential and $\mathrm{CO}_{2}$ is even more complex. Large values of the $\mathrm{CO}_{2}$ flux, larger than $1 \mathrm{~kg} \mathrm{~m}^{-2} \mathrm{~d}^{-1}$, can be associated with negative self-potential, as small as $-150 \mathrm{mV}$, but also with positive values clustered around $+40 \mathrm{mV}$ and also around zero.
[21] To examine this complex relationship between selfpotential and $\mathrm{CO}_{2}$, Figure 6 compares three $\mathrm{CO}_{2}$ profiles, the locations of which are shown in Figure 2, to the corresponding self-potential data interpolated from the self-potential map of Figure 5a. Profiles $\mathrm{C} 1$ and $\mathrm{P} 2$ are characterized by a negative self-potential at the flux maximum. The self-potential anomaly is narrower than the flux anomaly in $\mathrm{C} 1$ but it is larger in P2. Another case is profile $\mathrm{C} 2$, with the peak $\mathrm{CO}_{2}$ flux associated with a positive step of self-potential instead of a peak.

[22] To understand the observed pattern, hints may be obtained from the resistivity structure. The ERTb tomogram crosses the gas discharge zone GD1 while the ERTa profile is perpendicular to ERTb and is located at the zone with similar topographic variations as ERTb but outside of the gas discharges (see Figure 4). Tomogram ERTa reveals the structure of the shallow subsurface in a local reference zone (Figure 7b), free of self-potential anomaly (Figure 7a) and free of gas flow (Figure 4). This profile shows that the upper part of the topography, namely, the terrace, is composed of a moderately resistive layer with resistivity varying from 300 to $1500 \Omega \mathrm{m}$. Below this resistive layer, we observe an homogeneous conductive zone with a mean resistivity of 
a)

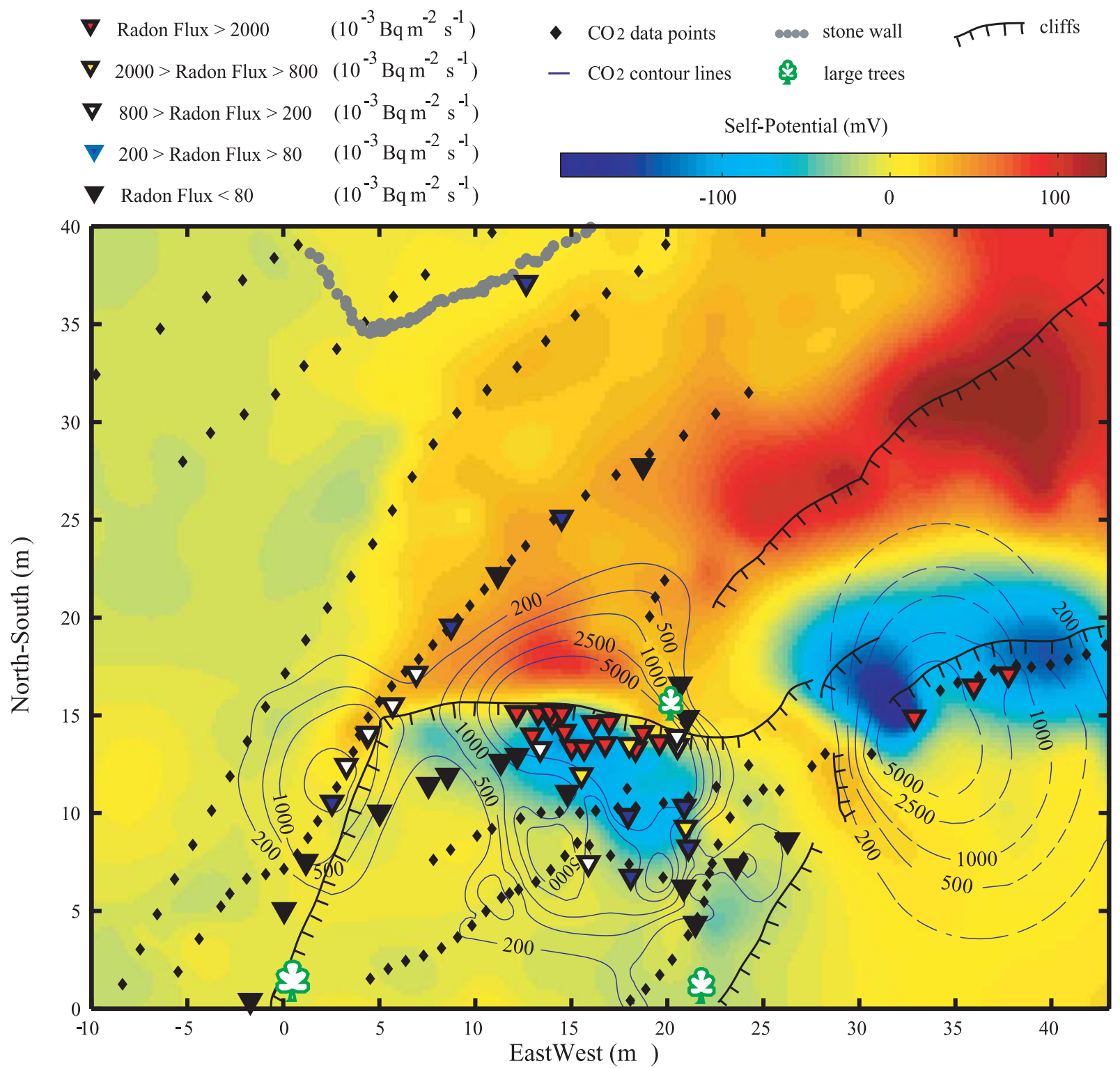

b)

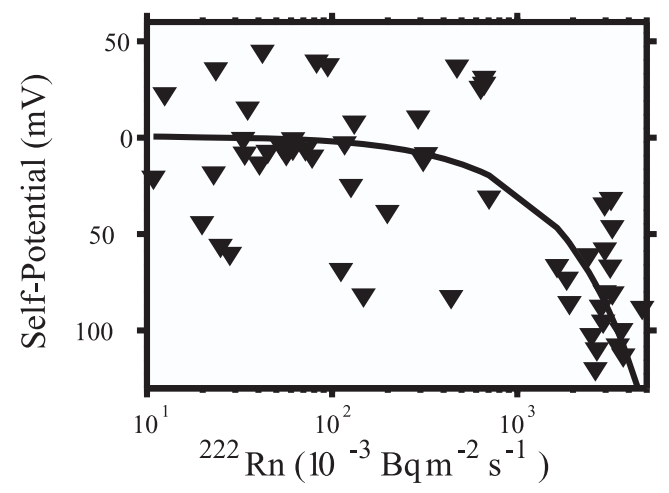

c)

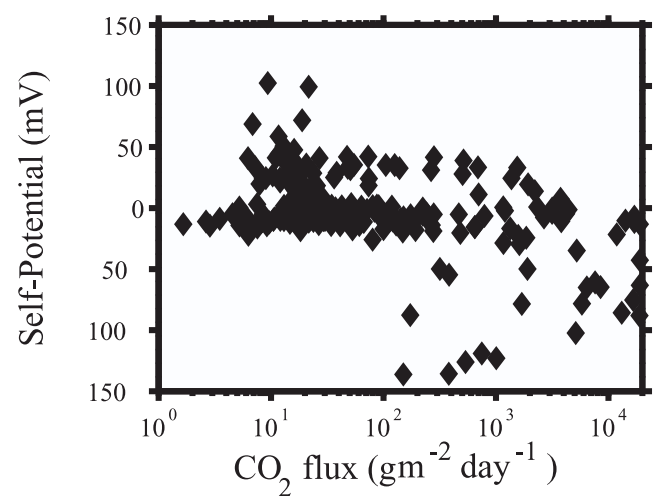

Figure 5. Details of the high-resolution survey (see position on Figure 4). (a) Self-potential map overlain with radon and $\mathrm{CO}_{2}$ flux values. Diamonds denote the $\mathrm{CO}_{2}$ flux values, and the filled triangles denote the ${ }^{222} \mathrm{Rn}$ flux stations with colors indicating the radon flux values. Blue lines contour $\mathrm{CO}_{2}$ flux values, and dashed lines are used in areas less covered by the data. (b) Self-potential versus ${ }^{222} \mathrm{Rn}$. The line corresponds to a least squares fit $\mathrm{SP}[\mathrm{mV}]=-0.05 \mathrm{Rn}$ flux $\left[10^{-3} \mathrm{~Bq} \mathrm{~m}^{-2} \mathrm{~s}^{-1}\right]$. (c) Self-potential versus $\mathrm{CO}_{2}$ flux values. 

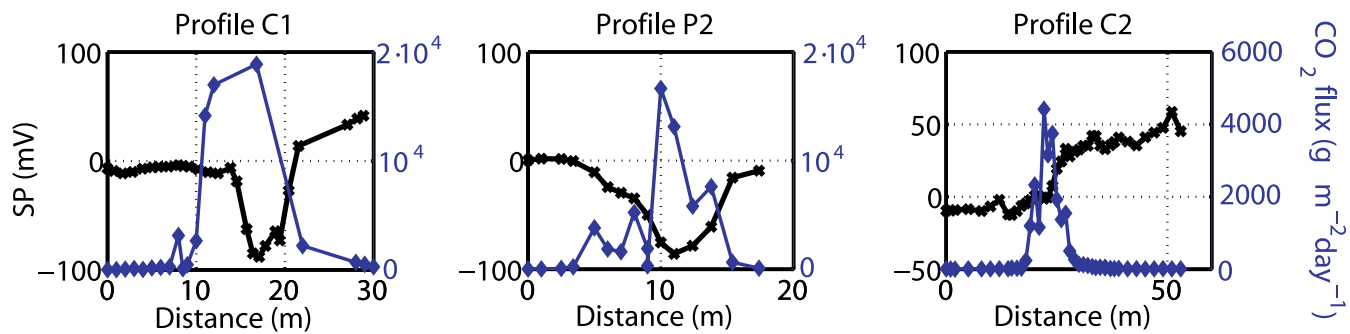

Figure 6. Self-potential and $\mathrm{CO}_{2}$ flux along $\mathrm{CO}_{2}$ profiles $\mathrm{C} 1, \mathrm{P} 2$, and $\mathrm{C} 2$ shown in Figure 2. Along profiles $\mathrm{C} 1$ and $\mathrm{P} 2$, crossing the main discharge zone GD1, the self-potential anticorrelates with $\mathrm{CO}_{2}$ flux data. Along profile $\mathrm{C} 2$, passing on the terrace above the gas discharge zone GD1, the maximum of the $\mathrm{CO}_{2}$ flux corresponds to a step in self-potential data and not to a minimum.

$\sim 50 \Omega \mathrm{m}$. Applying first Archie's law $\phi^{m}=\rho_{w} / \rho_{r}$, where $\rho_{w}=$ $5 \Omega \mathrm{m}$ is the resistivity of the spring water and $\rho_{w}=50 \Omega \mathrm{m}$ is the resistivity of this layer, we obtain its porosity, around $22 \%$ by taking $m=1.5$ or $36 \%$ with $m=2$. Such high values of porosity are not realistic in this context, thus, this conductive body corresponds likely to a clay rich, water saturated alluvial layer. The resistive body, barely seen in the bottom of the ERT section, could represent a boulder (Figure 2). Boulders are indeed numerous near the Trisuli River bed, in a deep valley, with summits at more than $3000 \mathrm{~m}$ altitude a few kilometers away.

[23] A different structure is revealed by profile ERTb, oriented perpendicular to the dipolar self-potential anomaly (Figure 4). While the general features of ERTa are recognized in this case, this time the conductive body is crossed by an oblique resistive channel with a resistivity of about $200-300 \Omega \mathrm{m}$ and a width of about $4 \mathrm{~m}$ (Figures $7 \mathrm{~d}$ and 8 ).

[24] The self-potential profile projected from the selfpotential map on the ERTb line is shown in Figure $7 \mathrm{c}$ together with the $\mathrm{CO}_{2}$ flux. The negative peak of the profile with amplitude of $-80 \mathrm{mV}$ coincides precisely with the maximum of the $\mathrm{CO}_{2}$ flux, an extreme value of $19 \mathrm{~kg} \mathrm{~m}^{-2} \mathrm{~d}^{-1}$, and with the top of the oblique resistive channel (Figure $7 \mathrm{~d}$ ). We therefore suggest to interpret the resistive channel as a preferential pathway for the gas and the hot hydrothermal water. Indeed, the presence of gas in a poorly consolidated material increases the resistivity of this material [Revil et al., 1999]. Applying crudely the second Archie law $\rho\left(S_{w}\right)=\rho / S_{w}^{2}$ (where the $\rho\left(S_{w}\right)=200 \Omega \mathrm{m}$ is the resistivity of the material at the relative water saturation $S_{w}$ and $\rho=50 \Omega$ a)

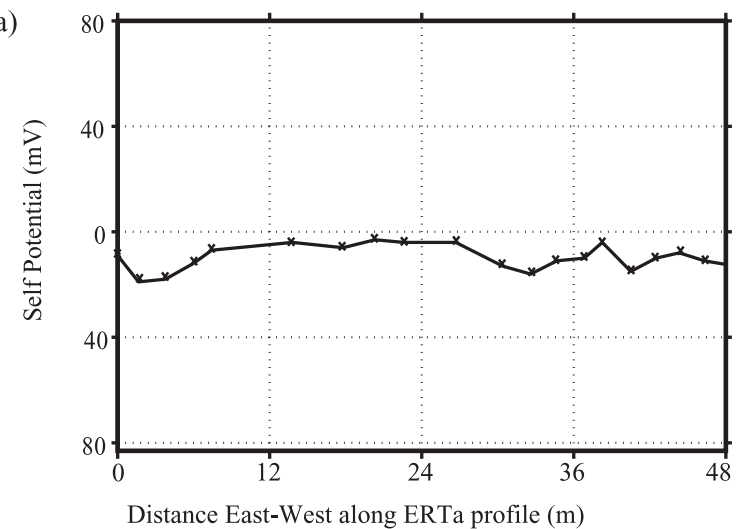

b)

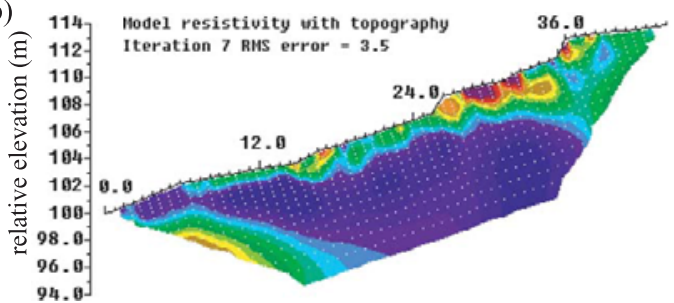

c)

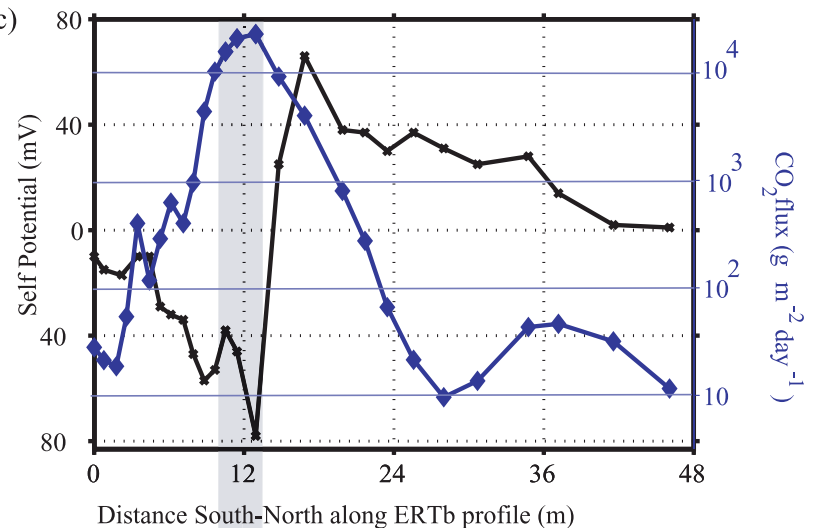

d)

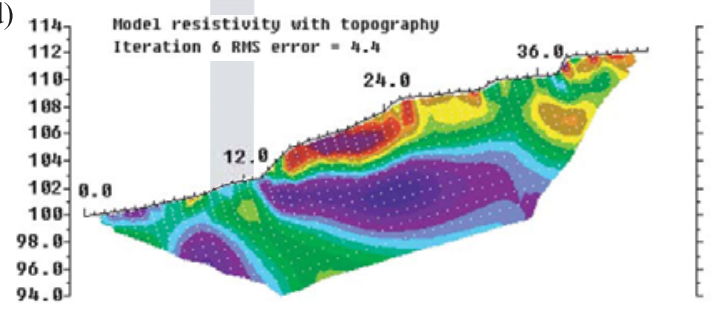

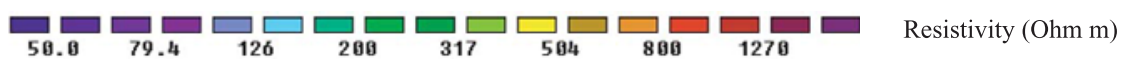

Figure 7. Electrical resistivity tomograms ERTa and ERTb and interpolated $\mathrm{CO}_{2}$ flux and self-potential data. Zero point for both profiles is the reference tree. (a and b) Self-potential and resistivity tomogram along the ERTa profile. This profile is used as a reference located outside the degassing area. (c and d) Self-potential profile and interpolated $\mathrm{CO}_{2}$ flux values along ERTb profile. 

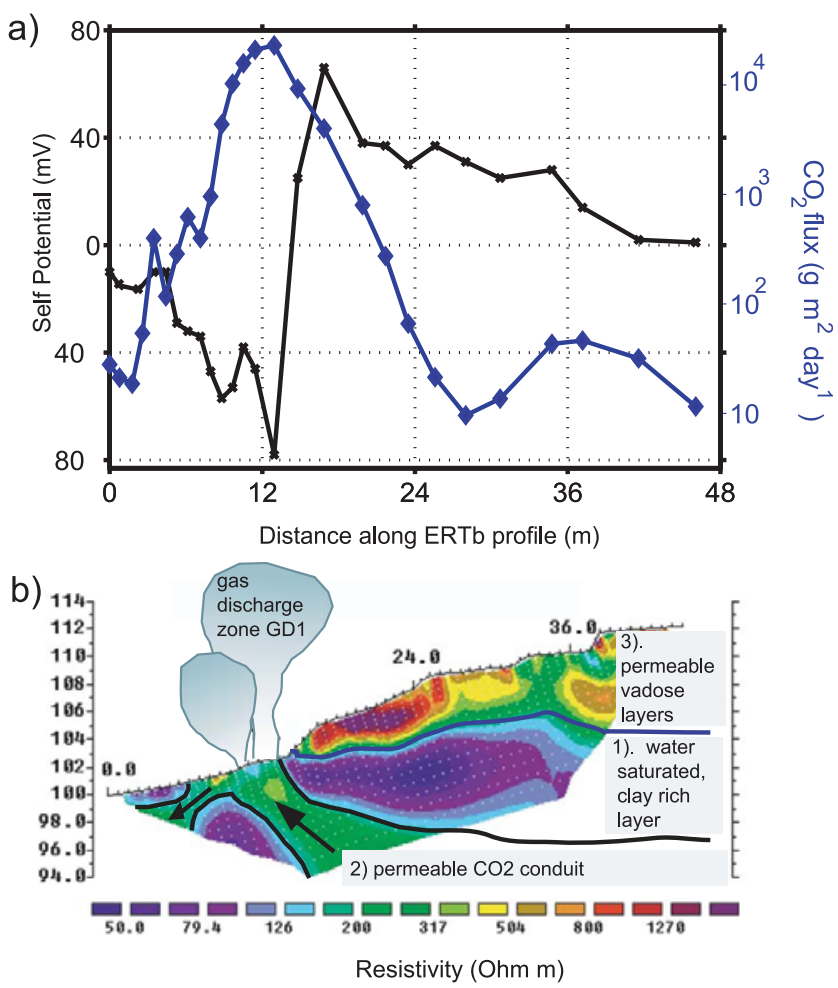

Figure 8. (s) Sketch of the plumbing system associated with the gas exhalations. (b) The ERT tomogram suggests the existence of three distinct zones: zone 1 is a watersaturated clayey soil layer (resistivity $50 \pm 10 \Omega \mathrm{m}$ ), zone 2 is a preferential pathway (resistivity in the range 200$300 \Omega \mathrm{m}$ ), associated with high gas fluxes and negative selfpotential anomaly at the ground surface, and zone 3 is a vadose zone (resistivity $>500 \Omega \mathrm{m}$ ). The $\mathrm{CO}_{2}$ is released to the atmosphere, and the groundwater descends along the left part of the channel in the direction of the hot springs.

$\mathrm{m}$ is the resistivity of the rock at saturation), we obtain a mean water saturation inside the conduit that is equal to 0.50 ( $50 \%$ of the pore volume). Therefore, the upflow of the hot water seems to be mainly driven by the flow of the gas phase (Figure 8).

\section{Modeling and Discussion}

[25] In this section, we focus on the interpretation of the self-potential dipolar anomaly in the vicinity of the main gas zone GD1, best covered by self-potential, gas, and resistivity data. We propose here an interpretation of the selfpotential anomalies in relation to the $\mathrm{CO}_{2}$ flux anomalies and the resistivity tomograms. Because resistivity influences the distribution of the electrical equipotential lines, it is important to incorporate a reasonably accurate resistivity model inside any modeling of the self-potential response associated with the flow of the groundwater [Yasukawa et al., 2003; Aizawa et al., 2005; Uyeshima, 2007]. The accurate gas flux and resistivity data are available at the ERTb profile passing perpendicular to cliffs seen in Figure 2. Figure 2 shows that the cliffs appear as a boundary dividing the negative part of the self-potential anomaly, associated with a high gas fluxes, from the positive anomaly observed on the terrace above the cliffs. Thus, we consider the 2-D approximation as a reasonable assumption to carry out our numerical model. We use the finite difference code SP50100I, which is a version of the SPXCPL software of Sill and Killpack [1982].

[26] We summarize now the partial differential equations solved by this code. The constitutive equation describing the flow of the pore water through a porous material is the Darcy equation,

$$
\mathbf{u}=-K \nabla H,
$$

where $\mathbf{u}$ is the seepage velocity (in $\mathrm{m} \mathrm{s}^{-1}$ ) (Darcy velocity), $H$ is the pressure head (in $\mathrm{m}$ ), $K$ is the hydraulic conductivity (in $\mathrm{m} \mathrm{s}^{-1}$ ). $K=k \rho_{f} g / \eta_{f}$, where $k$ is the permeability (in $\mathrm{m}^{2}$ ), $\rho_{f}$ is the mass density (in $\mathrm{kg} \mathrm{m}^{-3}$ ), and $\eta_{f}$ is the dynamic shear viscosity (in Pa s) of the pore water. For steady state conditions,

$$
\nabla \cdot \mathbf{u}=s,
$$

where $s$ is a volumetric source/sink term.

[27] The total electrical current density $\mathbf{j}$ is given by a generalized Ohm law [Sill, 1983],

$$
\mathbf{j}=-\sigma \nabla \varphi-L \nabla H,
$$

where $\varphi$ is the electrical (self-) potential (in V), $\sigma$ is the electrical conductivity of the material, $\mathbf{j}_{\mathbf{s}}=-L \nabla H$ is the source (streaming) current density, and $L$ the streaming current coupling coefficient (in $\mathrm{A} \mathrm{m}^{-2}$ ). These equations are valid in the viscous laminar flow regime. An extension of this theory for water-saturated media in the inertial laminar flow regime has been available recently [Boléve et al., 2007a; Crespy et al., 2007]. This theory has also being extended recently to multiphase flow by Linde et al. [2007] and Revil et al. [2007].

[28] In the quasi-static limit of the Maxwell equations, the continuity equation for the electrical charge is

$$
\nabla \cdot \mathbf{j}=0
$$

and therefore the current density is conservative.

[29] If the fluid pressure term is expressed in the constitutive equations in terms of the hydraulic head, the streaming potential coupling coefficient is defined by

$$
C \equiv\left\{\frac{\partial \varphi}{\partial H}\right\}_{\mathbf{j}=0}=-L / \sigma
$$

and is expressed here in $\mathrm{V} \mathrm{m}^{-1}$. The streaming potential coupling coefficient is also often expressed in $\mathrm{V} \mathrm{Pa}^{-1}$ if pressure is used as the state variable.

[30] The streaming potential coupling coefficient depends mainly on the electrical conductivity of the pore water [Revil et al., 2003]. Perrier et al. [2002] report the results for their laboratory studies of the streaming potential coefficient of the rocks found along the MCT zone in Nepal. The values of the coupling coefficient vary from -1 to $-8 \mathrm{mV} \mathrm{m}^{-1}\left(-10 \times 10^{-8} \mathrm{~V} \mathrm{~Pa}^{-1}\right.$ to $\left.{ }^{-} 80 \times 10^{-8} \mathrm{~V} \mathrm{~Pa}^{-1}\right)$, which are reasonable values for an average electrolyte resistivity of $10-100 \Omega \mathrm{m}$ [Perrier et al., 2002]. A better 


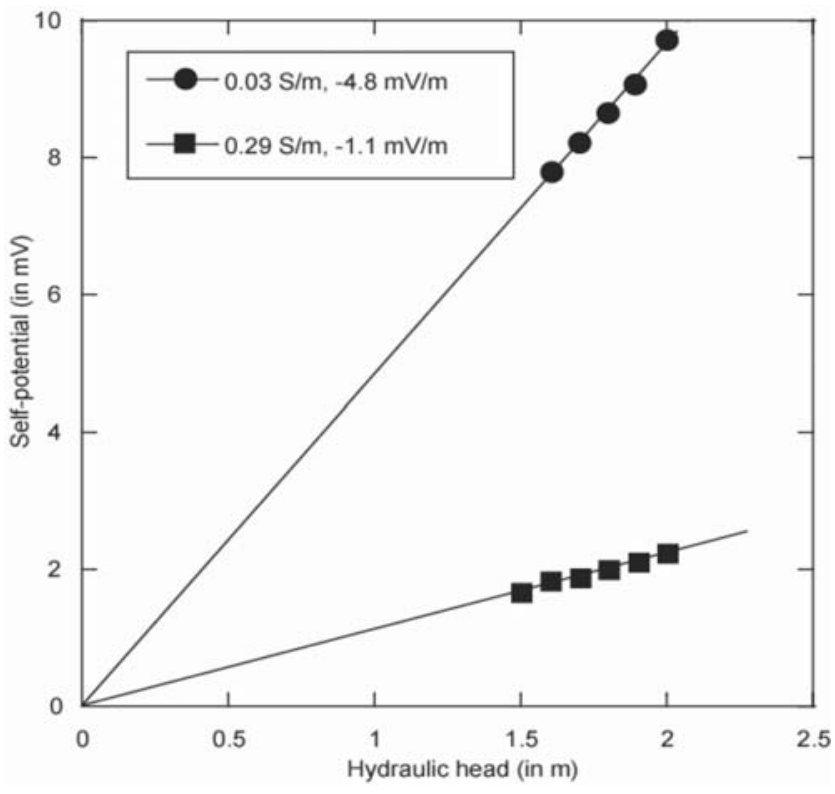

Figure 9. Measurement of the streaming potential coupling coefficient for a soil sample taken at $x=12 \mathrm{~m}$ in profile ERTb at two different pore water conductivities (0.03 and $\left.0.29 \mathrm{~S} \mathrm{~m}^{-1}\right)$.

estimate can be obtained by looking at the composition of the Syabru-Bensi hot springs and by performing direct measurements of the streaming potential coupling coefficient on core samples.

[31] The composition of the Syabru-Bensi hot springs have been measured in January 2004. The temperature of the source is in the range 32 to $62^{\circ} \mathrm{C}$. The $\mathrm{pH}$ is in the range 6.1 to 7.2. The electrical conductivity of the pore water is $\sigma_{f}=$ $0.17 \pm 0.03 \mathrm{~S} \mathrm{~m}^{-1}$. Measurements of the streaming coupling coefficient at two different pore water conductivities according to the method described by Suski et al. [2006] are shown in Figure 9 for one representative sample taken in the zone of maximum $\mathrm{CO}_{2}$ flux. This soil sample contains clays and sulfate minerals from the alteration of black shale formation. The streaming potential coupling coefficient $C$ for pore water conductivity of $\sigma_{f}=0.17 \mathrm{~S} \mathrm{~m}^{-1}$ can be then approximated as $\sim-2.0 \pm 0.5 \mathrm{mV} \mathrm{m}^{-1}\left(-20 \times 10^{-8} \mathrm{~V} \mathrm{~Pa}^{-1}\right)$. This value can be considered as the value of the streaming potential coefficient in the aquifer. On the basis of these results we can estimate the value of the coupling coefficient inside the conduit. According to Revil et al. [2007], the value of the streaming potential coupling coefficient $C\left(S_{w}\right)$ at saturation $S_{w}$, can be obtained approximately from the value of the streaming potential coupling coefficient at full saturation by $C\left(S_{w}\right)=C S_{w}$. Taking $C=-2 \mathrm{mV} \mathrm{m}^{-1}$ and $S_{w}$ $=0.50$, this yields a value of the coupling coefficient in the conduit of $\sim-1 \mathrm{mV} \mathrm{m}^{-1}\left(\sim-10 \times 10^{-8} \mathrm{~V} \mathrm{~Pa}^{-1}\right)$.

[32] In the numerical modeling code SP50100I used for this study, the equations for hydraulic (equation (2)) and electric potentials (equation (4)) are solved sequentially. They are coupled by the source term in equation (4) calculated from the solution of equation (2). For both equations, boundary conditions have to be imposed. In the case of groundwater flow problem, we consider a no-flow boundary condition except at the bottom of the system (see
Figure 10). For the self-potential problem, we use an insulating boundary condition at the ground-air interface.

[33] The partial differential equation (PDE) solver solves first the groundwater flow equation. Then the solution is used to compute the source term of the Poisson equation for the self-potential. For the groundwater flow problem, we consider a no-flow boundary condition except at the bottom of the system (see Figure 10). For the self-potential problem, we use an insulating boundary condition at the groundair interface.

[34] All models considered here include 100 horizontal cells by 50 vertical cells. The cell size is $x \times y=0.7 \times 0.4$ $\mathrm{m}$ except for the bottom layer where the vertical size is set to $20 \mathrm{~m}$. In order to avoid the influence of the model boundaries on the calculated self-potential, the mesh used for numerical modeling is larger than the original area of interest, defined by $A<x<D$ and $B<x<C$, respectively (Figure 10).

\subsection{Model M1: Meteoric Water Circulation in Homogeneous Medium}

[35] In a first model, we examine whether the observed self-potentials can be attributed solely to meteoric water flow along a topographic slope. All physical properties significant for the modeling ( $L, k$ and $\sigma$ ) are considered to be constant, e.g., all units have the same permeability. The meteoric water flowing owing to differences in topography encountered along the profile are supposed to be the only cause of the electrical current, no additional pressure sources are considered. The self-potential response for the M1 (green line in Figure 10c) shows an anticorrelation between the topography and the self-potential which have not been observed in our self-potential data. Furthermore, the M1 fails to account for the sign change at $12 \mathrm{~m}$ of the profile distance. This discrepancy between the results of the model M1 and the observed data have been anticipated from the field results obtained for the reference profile ERTa for which the approximations of the M1 seem realistic. Profile ERTa shows rather homogeneous resistivity distribution, gas flux measurements do not indicate any significant fluxes and no significant self-potential anomaly has been observed despite of the obvious topography.

\subsection{Model M2: Meteoric Water Circulation in a Medium With a Permeable Channel}

[36] In the next step, we introduce the permeable channel which existence can be concluded from our gas flux results. Model M2 contains a zone of higher permeability coinciding with a zone of $200 \Omega 4 \mathrm{~m}$ resistivity layer. No additional pressure sources are introduced. M2 corresponds to an assumption that permeable zones of high gas fluxes offer

Table 2. Physical Properties Used in Models 1-3

\begin{tabular}{llccr}
\hline & Unit & $\mathrm{k}\left(\mathrm{m}^{2}\right)$ & $\mathrm{C}\left(\mathrm{mV} \mathrm{m}^{-1}\right)$ & $\rho(\Omega \mathrm{m})$ \\
\hline Model M1 & $1-4$ & $10^{-15}$ & -2 & 50 \\
Model M2 & $1,3,4$ & $10^{-15}$ & -2 & 50 \\
& 2 & $2 \times 10^{-13}$ & -1 & 200 \\
Model M3 & 1 & $10^{-15}$ & -2 & 50 \\
& 2 & $2 \times 10^{-13}$ & -1 & 200 \\
& 3 & $3 \times 10^{-15}$ & -7 & 1200 \\
& 4 & $10^{-15}$ & -5 & 600 \\
\hline
\end{tabular}




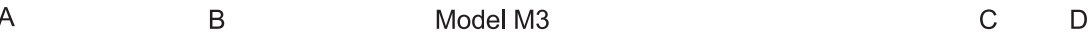

a)

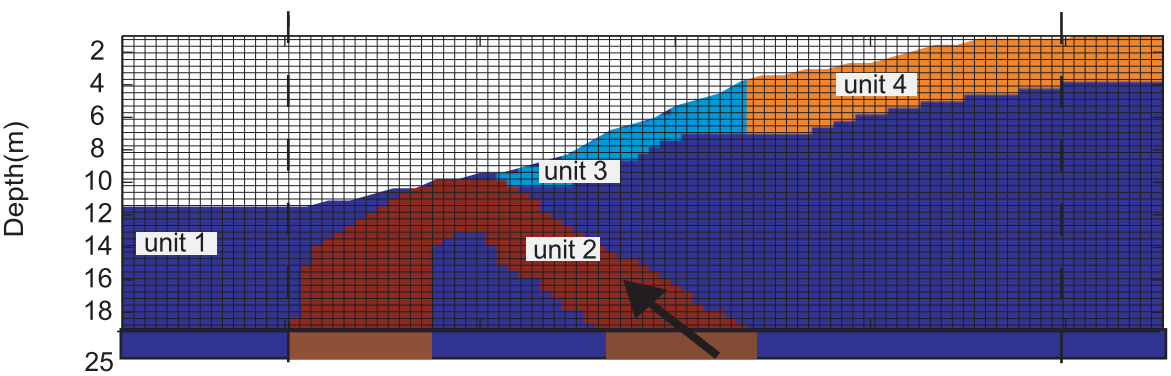

b)

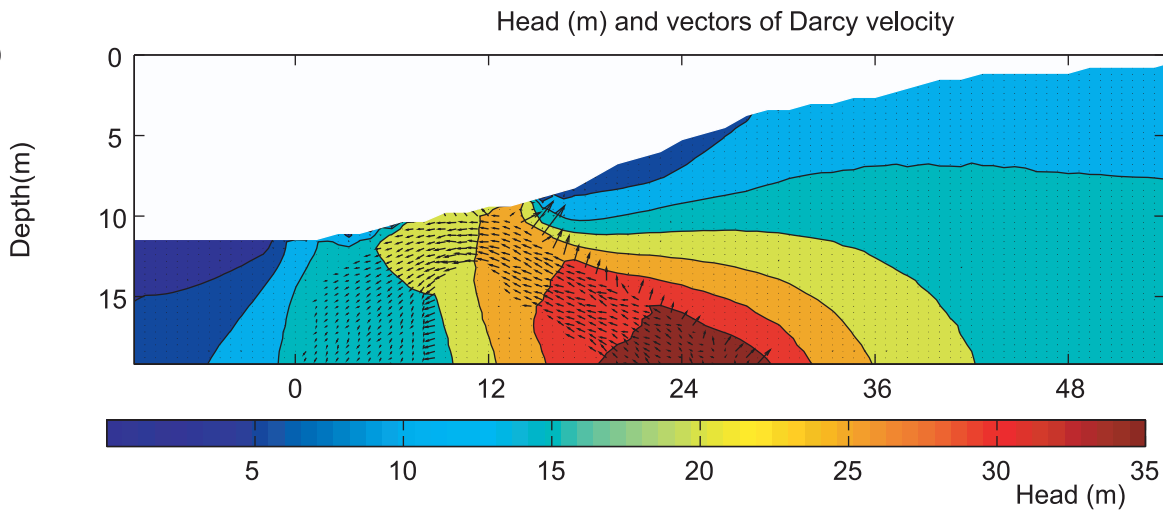

c)

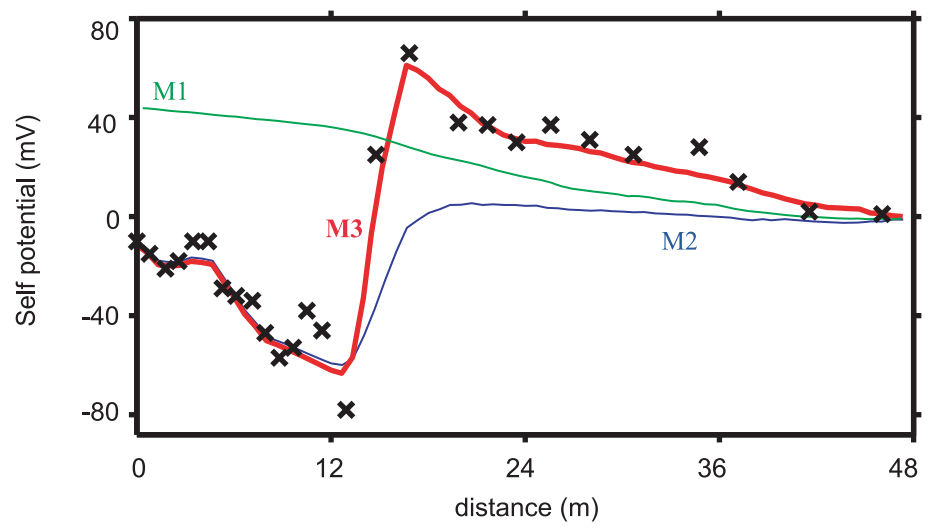

Figure 10. Numerical model M3. (a) The architecture of this model has four units with boundaries derived from the resistivity structure of the ERTb tomogram (located between points B and C). (b) Head distribution and Darcy velocity vectors calculated for the M3. (c) Self-potential data (crosses) and calculated SP response for models M1 (green line), M2 (blue line), and M3 (red line). Model M3 explains well the qualitative features of the observed self-potential data.

preferential pathways for the percolation of meteoric water. This model explains the minimum of the measured selfpotential at $12 \mathrm{~m}$ profile distance but not the maximum at 24 $\mathrm{m}$ profile distance (blue line in Figure 10c).

\subsection{Model M3: Convective Cell in a Medium With a Permeable Channel}

[37] To model the upflow of the hydrothermal water, a pressure source with an amplitude of $4 \times 10^{5} \mathrm{~Pa}$ (which corresponds to $40 \mathrm{~m}$ in units of $H$ ) is introduced at the bottom of the model, at depth of $25 \mathrm{~m}$. Both the amplitude and the depth of the source was chosen by trial and error to fit the observed self-potential data. This pressure source acts in our model as a "surrogate" force replacing the unknown pressure distribution driving the ascent of $\mathrm{CO}_{2}$ from the depth of few kilometers to the surface. The physical parameters of this model are reported in Table 2. With the characteristics listed in Table 2, the finite difference simulation, shown in Figure 10, agrees well with the observed self-potential data collection along profile ERTb (RMS = $6.2 \mathrm{mV})$.

[38] In M3 the Darcy velocity in unit 2 is $10^{-4} \mathrm{~m} \mathrm{~s}^{-1}$ which corresponds by a saturation of $50 \%$ to the $\mathrm{CO}_{2}$ flux $7.5 \mathrm{~kg} \mathrm{~m}^{-2} \mathrm{~s}^{-1}$. This value fits nicely to the average $\mathrm{CO}_{2}$ flux value above the top permeable channel (marked by grey rectangle in Figures $7 \mathrm{c}$ and $7 \mathrm{~d}$ ). While our proposed 
solution cannot be proven to be unique, alternative interpretations with other flow geometries are not easy to find because of the constrains given by the resistivity and selfpotential and gas flux data together with a position of the gas discharges.

\section{Conclusions}

[39] A high-resolution self-potential map has been obtained at the main gas discharge points and hot springs located in a major fault zone in central Nepal. This map reveals two clear dipolar self-potential anomalies with an amplitude of several hundreds of millivolts. An electrical resistivity tomogram indicates a dipping $200 \Omega \mathrm{m}$ resistive structure, the top of which coincides with the main gas discharge and with the negative peak of the self-potential anomaly. Our interpretation is that the resistive structure represents a permeable fracture zone serving as a preferential pathway for the flow of gas and water. The presence of gas decreases the conductivity with respect to the host material. This structure is surrounded at the depth of several meters by a conductive medium $(50 \Omega \mathrm{m})$ and by a highresistivity $(600-1200 \Omega \mathrm{m})$ overburden close to the surface on the northern part of the profile. To explain the observed self-potential anomaly, we assume that the fluid flow is ascending along the $200 \Omega \mathrm{m}$ permeable pathway and to account for the negative pole, we introduce a descending flow to the south of the profile, in the direction of the hot springs.

[40] This model offers a good representation of the selfpotential data using values of the coupling parameters that have been determined independently. Nevertheless, the estimate of the numerical parameters of the model is not unique and the magnitude of the pressure source is not known a priori. In addition, the model does not account for all the observed physical properties of the system, such as the details of the relationship between self-potential and $\mathrm{CO}_{2}$ flux. In this context, the 2-D assumption is surely a strong approximation. Despite these limitations, thanks to the constrains given by the electrical resistivity tomogram, self-potential and flux data, the flow configuration is well constrained and remains the most robust result of our study. For the development of the conceptual model and the parameterization for the simulation, the knowledge of the resistivity structure was of utmost importance.

[41] This study provides an example of a self-potential spatial distribution interpreted in the context of heterogeneous electrical properties. In addition, it provides an example of a dipolar self-potential anomaly interpreted as a upward-downward flow pair, the former driven by vigorous gas ascent, the latter by topography. This flow configuration may be a general feature of geothermal systems with large gas release.

[42] To evaluate the physical processes, it may be important to assess the temporal variations of the self-potentials in Syabru-Bensi. This could be crucial to identify possible components associated with meteorological effects, in particular rainfall or shallow ground water table variations, for example, associated with seasonal effects like monsoon. Additional mechanisms, for example, associated with gradients of concentrations or temperature, could also contrib- ute to the observed self-potentials. To make progress on the interpretation, it may also be interesting to consider a comparative modeling approach of the few known dipolar self-potential anomalies. To assess the general versus particular features of the self-potentials observed in SyabruBensi, self-potential mapping should also be performed in other similar geothermal sites in central Nepal. These sites offer excellent opportunities for testing in details our understanding of hydroelectrical coupling, and the contribution of two-phase fluid flow. These geothermal systems are also particularly interesting because the fluid variations at the origin of the observed effects may be sensitive to forcing factors such as stress variations.

[43] Acknowledgments. The authors thank the Central Department of Geology, Tribhuvan University Kathmandu, Nepal, for providing equipment for the ERT survey; D. K. Butler (U.S. Army Engineer Waterways Experiment Station, Mississippi) and V. Rath (Aachen University, Germany) for making the code SP50100I for the self-potential modeling available to us; the Department of Mines and Geology for his support; and R. Raut for assistance during the field work. We thank the reviewers for their constructive contributions to our manuscript. This paper is IPGP contribution 2526

\section{References}

Aizawa, K., et al. (2005), Hydrothermal system beneath Mt. Fuji volcano inferred from magnetotellurics and electric self-potential, Earth Planet. Sci. Lett., 235, 343-355, doi:10.1016/j.epsl.2005.03.023.

Apostolopoulos, G., I. Louis, and E. Lagious (1997), The self-potential method in the geothermal exploration of Greece, Geophysics, 62(6), 1715-1723, doi:10.1190/1.1444271.

Becker, J., M. Bickle, A. Galy, and T. Holland (2008), Himalayan metamorphic $\mathrm{CO}_{2}$ fluxes: quantitative constraints from hydrothermal springs, Earth Planet. Sci. Lett., 265, 616-629, doi:10.1016/j.eps1.2007.10.046.

Boléve, A., A. Crespy, A. Revil, F. Janod, and J. L. Mattiuzzo (2007a), Streaming potentials of granular media: Influence of the Dukhin and Reynolds numbers, J. Geophys. Res., 112, B08204, doi:10.1029/ 2006JB004673.

Boléve, A., A. Revil, F. Janod, J. L. Mattiuzzo, and A. Jardani (2007b), Forward modeling and validation of a new formulation to compute selfpotential signals associated with ground water flow, Hydrol. Earth Syst. Sci., 11, 1661-1671.

Bollhöfer, A., J. Storm, P. Martin, and S. Tims (2006), Geographic variability in radon exhalation at a rehabilitated uranium mine in the Northern Territory, Australia, Environ. Monit. Assess., 114, 313-330, doi:10.1007 s10661-006-4777-z.

Bollinger, L., J. P. Avouac, R. Cattin, and M. R. Pandey (2004), Stress buildup in the Himalaya, J. Geophys. Res., 109, B11405, doi:10.1029 2003JB002911.

Bollinger, L., P. Henry, and J. Avouac (2006), Mountain building in the Nepal Himalaya: Thermal and kinematic model, Earth Planet. Sci. Lett. 244, 58-71, doi:10.1016/j.eps1.2006.01.045.

Castermant, J., C. Mendonca, A. Revil, F. Trolard, G. Bourrie, and N. Linde (2008), Redox potential distribution inferred from self-potential measurements during the corrosion of a burden metallic body, Geophys. Prospect., 56, 269-282, doi:10.1111/j.1365-2478.2007.00675.x.

Constable, S., R. Parker, and C. Constable (1987), Occam inversion- a practical algorithm for generating smooth models from electromagnetic sounding data, Geophysics, 52, 289-300, doi:10.1190/1.1442303.

Corwin, R., and D. Hoover (1979), The self-potential method in geothermal exploration, Geophysics, 44(2), 226-242, doi:10.1190/1.1440964.

Corwin, R. F., and D. V. Fitterman (1982), Geological interpretation of selfpotential data from the Cerro Prieto geothermal field, Geophysics, 47(6), 938-945, doi:10.1190/1.1441361.

Crespy, A., A. Boleve, and A. Revil (2007), Influence of the Dukhin and Reynolds numbers on the apparent zeta potential of granular media, J. Colloid Interface Sci., 305, 188-194, doi:10.1016/j.jcis.2006.09.038. Crespy, A., A. Revil, N. Linde, S. Byrdina, A. Jardani, A. Boleve, and P. Henry (2008), Detection and localization of hydromechanical disturbances in a sandbox using the self-potential method, J. Geophys. Res., 113, B01205, doi:10.1029/2007JB005042.

Darnet, M., A. Maineult, and G. Marquis (2004), On the origins of selfpotential (SP) anomalies induced by water injections into geothermal reservoirs, Geophys. Res. Lett., 31, L19609, doi:10.1029/2004GL020922. 
Evans, M. J., L. A. Derry, and C. France-Lanord (2004), Geothermal fluxes of alkalinity in the Narayani river system of central Nepal, Geochem. Geophys. Geosyst., 5, Q08011, doi:10.1029/2004GC000719.

Evans, M. J., L. A. Derry, and C. France-Lanord (2008), Degassing of metamorphic carbon dioxide from the Nepal Himalaya, Geochem. Geophys. Geosyst., 9, Q04021, doi:10.1029/2007GC001796.

Finizola, A., F. Sortino, J. Lenat, M. Aubert, M. Ripepe, and M. Valenza (2003), The summit hydrothermal system of Stromboli. New insights from self-potential, temperature, $\mathrm{CO}_{2}$ and fumarolic fluid measurements with structural and monitoring implications, Bull. Volcanol., 65, 486-504, doi:10.1007/s00445-003-0276-z.

Finizola, A., J.-F. Lenat, O. Macedo, D. Ramos, J. Thouret, and F. Sortino (2004), Fluid circulation and strcutural discontinuities inside Misti volcano (Peru) inferred from self-potential measurements, J. Volcanol. Geotherm. Res., 135, 343-360, doi:10.1016/j.jvolgeores. 2004.03.009.

Finizola, A., A. Revil, E. Rizzo, S. Piscitelli, T. Ricci, J. Morin, B. Angeletti, L. Mocochain, and F. Sortino (2006), Hydrogeological insights at Stromboli volcano (Italy) from geoelectrical, temperature, and $\mathrm{CO}_{2}$ soil degassing investigations, Geophys. Res. Lett., 33, L17304, doi:10.1029/ 2006GL026842.

Goldstein, N. E., S. Halfma, R. F. Convint, and J. R. Alvarez (1989), Selfpotential anomaly changes at the East Mesa and Cerro Prieto geothermal fields, paper presented at 14th Workshop on Geothermal Reservoir Engineering, Stanford Univ., Stanford, Calif.

Ishido, T., and J. W. Pritchett (1999), Numerical simulation of electrokinetic potentials associated with subsurface fluid flow, J. Geophys. Res., 104(B7), 15,247-15,259, doi:10.1029/1999JB900093

Ishido, T., T. Kikuchi, N. Matsushima, Y. Yano, S. Nakao, M. Sugihara T. Tosha, S. Takakura, and Y. Ogawa (1997), Repeated self-potential profiling of Izu-Oshima volcano, Japan, J. Geomagn. Geoelectr., 49, $1267-1278$

Jardani, A., J. P. Dupont, and A. Revil (2006), Self-potential signals associated with preferential groundwater flow pathways in sinkholes, J. Geophys. Res., 111, B09204, doi:10.1029/2005JB004231.

Jardani, A., A. Revil, A. Bolève, and J. P. Dupont (2008), Three-dimensional inversion of self-potential data used to constrain the pattern of groundwater flow in geothermal fields, J. Geophys. Res., 113, B09204, doi:10.1029/ 2007JB005302

Lavé, J., D. Yule, S. Sapkota, K. Basant, C. Madden, M. Attal, and R. Pandey (2005), Evidence for a Great Medieval Earthquake ( 1100 A.D.) in the Central Himalayas of Nepal, Science, 307, 1302-1305, doi:10.1126/ science. 1104804 .

Lénat, J. F., B. Robineau, S. Durand, and P. Bachelery (1998), A selfpotential survey of the summit zone of Karthala volcano (Grande Comore), C. R. Acad. Sci., Ser. II, 327, 781-788.

Lewicki, J. L., C. Connor, K. St-Amand, J. Stix, and W. Spinner (2003), Self-potential, soil $\mathrm{CO}_{2}$ flux, and temperature on Masaya volcano, Nicaragua, Geophys. Res. Lett., 30(15), 1817, doi:10.1029/ 2003GL017731.

Linde, N., D. Jougnot, A. Revil, S. K. Matthai, T. Arora, D. Renard, and C. Doussan (2007), Streaming current generation in two-phase flow conditions, Geophys. Res. Lett., 34, L03306, doi:10.1029/ 2006GL028878

Loke, M., and R. D. Barker (1996), Rapid least-squares inversion of apparent resistivity pseudosections by a quasi-Newton method, Geophys. Prospect., 44, 131-152, doi:10.1111/j.1365-2478.1996.tb00142.x.

Maineult, A., M. Darnet, and G. Marquis (2006), Correction to "On the origins of self-potential (SP) anomalies induced by water injections into geothermal reservoirs", Geophys. Res. Lett., 33, L20319, doi:10.1029/ 2006GL028211.

Minsley, B. J., J. Sogade, and F. Morgan (2007), Three-dimensional selfpotential inversion for subsurface DNAPL contaminant detection at the Savannah River Site, South Carolina, Water Resour. Res., 43, W04429, doi:10.1029/2005WR003996.

Naudet, V., A. Revil, J.-Y. Bottero, and P. Begassat (2003), Relationship between self-potential (SP) signals and redox conditions in contaminated groundwater, Geophys. Res. Lett., 30(21), 2091, doi:10.1029 2003GL018096.

Nourbehecht, B. (1963), Irreversible thermodynamic effects in inhomogeneous media and their application in certain geoelectric problems, $\mathrm{Ph} . \mathrm{D}$ thesis, Mass. Inst. Technol., Cambridge.

Olayinka, A. I., and U. Yaramanci (2000), Use of block inversion in the 2-D interpretation of apparent resistivity data and its comparison with smooth inversion, J. Appl. Geophys., 45(2), 63-81, doi:10.1016/S09269851(00)00019-7.

Pandey, M., R. Tandukar, J. Avouac, J. Vergne, and T. Heritier (1999), Seismotectonics of the Nepal Himalaya from a local seismic network, J. Asian Earth Sci., 17, 703-712, doi:10.1016/S1367-9120(99)00034-6.
Park, S., W. Dalrymple, and J. C. Larsen (2007), Parkfield earthquake: Test of the electromagnetic precursor hypothesis, J. Geophys. Res., 112, B05302, doi:10.1029/2005JB004196.

Perrier, F., G. Chitrakar, T. Froidefond, D. Tiwari, U. Gautam, B. Kafle, and M. Trique (2002), Estimating streaming potentials associated with geothermal circulation at the Main Central Thrust: An example from Tatopani-Kodari hot spring in central Nepal, J. Nepal Geol. Soc., 26, $17-27$.

Perrier, F., et al. (2009), High carbon dioxide and radon-222 gas exhalation at the Syabru-Bensi hot springs in central Nepal, Earth Planet. Sci. Lett. 278, 198-207, doi:10.1016/j.eps1.2008.12.008

Petiau, G. (2000), Second generation of lead-lead chloride electrodes for geophysical applications, Pure Appl. Geophys., 157, 357-382, doi: $10.1007 / \mathrm{s} 000240050004$.

Revil, A., and L. M. Cathles (2002a), Fluid transport by solitary waves along growing faults: A field example from the South Eugene Island Basin, Gulf of Mexico, Earth Planet. Sci. Lett., 204(1-2), 321-335, doi:10.1016/S0012-821X(02)01001-4.

Revil, A., and L. M. Cathles (2002b), Fluid transport by solitary waves along growing faults: A field example from the South Eugene Island Basin, Gulf of Mexico, (erratum), Earth Planet. Sci. Lett., 204(1-2), 321-322, doi:10.1016/S0012-821X(02)01001-4.

Revil, A., and P. A. Pezard (1998), Streaming electrical potential anomaly along faults in geothermal areas, Geophys. Res. Lett., 25(16), $3197-$ 3200, doi:10.1029/98GL02384.

Revil, A., P. A. Pezard, and P. W. J. Glover (1999), Streaming potential in porous media: 1. Theory of the zeta potential, J. Geophys. Res., 104, 20,021-20,031, doi:10.1029/1999JB900089.

Revil, A., V. Naudet, J. Nouzaret, and M. Pessel (2003), Principles of electrography applied to self-potential electrokinetic sources and hydrogeological applications, Water Resour. Res., 39(5), 1114, doi:10.1029/ 2001WR000916.

Revil, A., A. Finizola, F. Sortino, and M. Ripepe (2004), Geophysical investigations at Stromboli volcano, Italy. Implications for ground water flow and paroxysmal activity, Geophys. J. Int., 157(1), 426-440, doi:10.1111/j.1365-246X.2004.02181.x

Revil, A., Q. Fan, L. Cary, A. Finizola, and F. Trolard (2005), Negative self-potential signals associated with preferential ground water flow pathways in a buried paleo-channel, Geophys. Res. Lett., 32, L07401, doi:10.1029/2004GL022124.

Revil, A., N. Linde, A. Cerepi, D. Jougnot, S. Matthai, and S. Finsterle (2007), Electrokinetic coupling in unsaturated porous media, J. Colloid Interface Sci., 313, 315-327, doi:10.1016/j.jcis.2007.03.037.

Revil, A., et al. (2008), Inner structure of La Fossa di Vulcano (Vulcano Island, southern Tyrrhenian Sea, Italy) revealed by high resolution electric resistivity tomography coupled with self-potential, temperature, and soil $\mathrm{CO}_{2}$ diffuse degassing measurements, J. Geophys. Res., 113 B07207, doi:10.1029/2007JB005394

Sandwell, D. T. (1987), Biharmonic spline interpolation of GEOS-3 and SEASAT altimeter data, Geophys. Res. Lett., 14(2), 139-142, doi:10.1029/GL014i002p00139.

Sasai, Y., J. Zlotnicki, Y. Nishida, Y. Tanaka, P. Yvetot, P. Morat, and H. Murakami (1997), Electromagnetic monitoring of Miyake-jima Volcano, Izu-Bonin Arc, Japan: A preliminary report, J. Geomagn. Geoelectr. 49, 1293-1316.

Schima, S., M. Wilt, and H. Ross (1995), Modeling self-potential data in the Abraham and Meadow-Hatton hydrothermal systems: The search of upflow zones, paper presented at Annual Meeting of the Geotherm. Resour. Counc., Reno, Nev., 8-11 Oct.

Sill, W., and T. Killpack (1982), SPXCPL: Two-dimensional modeling program of self-potential effects from cross-coupled fluid and heat flow, user's guide and documentation for version 1.0, NASA STI/Recon Tech. Rep., 83, 13,400.

Sill, W. R. (1983), Self-potential modeling from primary flows, Geophysics, 48(1), 76-86, doi:10.1190/1.1441409.

Suski, B., A. Revil, K. Titov, P. Konosavsky, M. Voltz, C. Dages, and O. Huttel (2006), Monitoring of an infiltration experiment using the self-potential method, Water Resour. Res., 42, W08418, doi:10.1029/ 2005WR004840.

Upreti, B. (1999), An overview of the stratigraphy and tectonics of the Nepal Himalaya, J. Asian Earth Sci., 17, 577-606, doi:10.1016/ S1367-9120(99)00047-4

Uyeshima, M. (2007), EM monitoring of Crustal Processes Including the Use of the Network-MT observations, Surv. Geophys., 28, 199-237, doi:10.1007/s10712-007-9023-x.

Ward, S. (1989), Resistivity and induced polarization methods, in Geotechnical and Environmental Geophysics, Invest. Geophys., vol. 5, edited by S. Ward, pp. 147-189, Soc. of Explor. Geophys., Tulsa, Okla.

Wilkinson, P., J. Chambers, P. I. Meldrum, R. D. Ogilvy, C. J. Mellor, and S. Caunt (2005), A comparison of self-potential tomography with elec- 
trical resistivity tomography for the detection of abandoned mineshafts, J. Environ. Eng. Geophys., 10(4), 381-389, doi:10.2113/JEEG10.4.381.

Yasukawa, K., G. Bodvarsson, and M. Wilt (1993), A coupled self-potentia and mass-heat flow code for geothermal applications, Trans. Geotherm. Resour. Counc., 17, 203-207.

Yasukawa, K., T. Mogi, D. Widarto, and S. Ehara (2003), Numerical modeling of a hydrothermal system around Waita volcano, Kyushu, Japan, based on resistivity and self-potential survey results, Geothermics, 32, 21-46, doi:10.1016/S0375-6505(02)00048-2.

Zlotnicki, J., and Y. Nishida (2003), Review on morphological insights of self-potential anomalies on volcanoes, Surv. Geophys., 24, 291-338, doi:10.1023/B:GEOP.0000004188.67923.ac.

S. Byrdina, Laboratoire Magmas et Volcans Observatoire de Physique du Globe de Clermont-Ferrand, Université Blaise Pascal, IRD M163, UMR
6524, 5 rue Kessler, F-63038 Clermont-Ferrand, France. (S.Byrdina@opgc. univbpclermont.fr)

S. Contraires, Equipe de Géomatériaux et Environnement, IPGP, UMR 7154, 4, Place Jussieu, F-75005 Paris, France.

U. P. Gautam, B. P. Koirala, S. N. Sapkota, P. L. Shrestha, and D. R. Tiwari, National Seismological Centre, Department of Mines and Geology, Lainchaur, Kathmandu, Nepal.

S. R. Pant and K. Shrestha, Central Department of Geology, Tribhuvan University, Kirtipur, Nepal.

F. Perrier, Université Paris Diderot, IPGP, UMR 7154, 4, Place Jussieu, F-75005 Paris, France.

A. Revil, Colorado School of Mines, Green Center, Department of Geophysics, 1500 Illinois Street, Golden, CO, USA. (arevil@mines.edu) 